\title{
LONG-TERM COCONUT LEAF PRUNING (CLP) EFFECTS ON CBFS: COCONUT-COFFEE AGROECOSYSTEM
}

\author{
By
}

\author{
L.H. Canja ${ }^{1}$, S.S. Magat ${ }^{2}$, and, R.Z. Margate . ${ }^{1}$
}

\begin{abstract}
A long-term study on the response of 'Laguna' tall (LAGT) palms and coffee intercrop to coconut leaf pruning (CLP) was conducted at the PCA-Davao Research Center from 1993 to 2001 to determine the effect of coconut leaf pruning on the productivity of coconut + coffee cropping system.

The coconut leaf pruning technique did not significantly affect the yield and nutrition of coconut in all the years of observation. However, lower number of nut and weight of copra per tree were observed on palms with CLP than those without CLP, but with a slight improvement in copra weight per nut.

Likewise, CLP did not affect the coffee yield and leaf nutrient levels. Among the coffee varieties tested, the Excelsa had the highest green bean yield. The Robusta (Ivory Coast and Philippine strains) and Arabica had similar yield and crop nutritional status. While they had similar leaf $N, K$ and $B$ contents that were higher than that of Excelsa, they also had lower leaf levels of $\mathrm{Ca}, \mathrm{Cl}$ and $\mathrm{S}$.

Coffee needs, 1,000-3,000 foot-candles of sunlight, which is within the available light transmission (1,750-4,050 foot-candles) under palms with and without CLP. Hence, CLP is not necessary anymore in coconut with coffee intercrop.
\end{abstract}

Keywords: Coconut leaf pruning, leaf rank 19, leaf rank 23, foot-candle

\section{INTRODUCTION}

The effect of the removal or pruning of leaves of coconut on its production is not well understood. In fact, during harvesting, leaves are usually removed to facilitate the process of cutting harvestable bunches. In Davao, Southern Mindanao, only few leaves (5-10) are left to allow adequate sunlight for the normal development and high yield of ramie intercrop and other annual crops.
Depending on the extent of pruning of palms, some workers obtained adverse effects (Bailey et al., 1977; Calvez, 1976). However, other workers reported beneficial effects of the practice on plants (Gifford and Evans, 1981; Delting et al., 1979; Heichel and Turner, 1985). In coconut, it should be very useful to understand the response of palms to pruning as this has several implications on cultural and cropping systems as intercropping, irrigation, drought

1 PCA-Davao Research Center, Bago Oshiro, Davao City, Philippines

2 PCA-Agricultural Research Management Department-Research Development and Extension Branch, Quezon City, Philippines 
tolerance, pest control management as well as additional income from sale of pruned leaves and their by-products. Coffee is one of the most popular and widely used intercrops for coconut that can withstand shading. De Geus (1967) added that coffee is by nature suited for growing without shade but can be grown with shade.

Coffee responds to filtered to moderate sunlight. For this reason much of the world's coffee is grown under shade trees which also protect against the overhead tropical sun. They grow on mountainsides that make for natural partial lighting conditions. However, some types of coffee plants can take direct sunlight without overhead shade trees or a mountainside cutting off a half-day light.

Traditionally, coffee has been grown as a crop within the mixed-shade cover of fruit trees and other hardwood species, which together form a forest-like agroecosystem (www.wri.org). De Rosayro (2001) added that in Africa, a coffee-forestry-integrated approach is at present being adopted, and there is a spreading use of a good fast-growing timber species (Grevellia robusta) for shade. During the mid- $20^{\text {th }}$ century, farmers were encouraged to grow coffee in full sun to improve yields and reduce fungal infection. However, widespread acceptance of this practice did not take place until the 1970's (Perfecto et al., 1996). It was also reported that new coffee hybrids were developed for sun tolerance and compact growth therefore yielding more coffee per hectare (www.geocities.com). However, coffee plants exposed to the open sun are more susceptible to disease and require large applications of expensive chemicals (www.seattleaudubon.org).

The study was conducted for eight years at the Philippine Coconut Authority-Davao Research Center, Bago Oshiro, Davao City to determine the effect of coconut leaf pruning on the productivity of coffee and coconut in a coconut+coffee cropping system.

\section{MATERIALS AND METHODS}

\subsection{Experimental Materials and Site}

Bearing Laguna tall palms distanced $8 \mathrm{x} 8$ meters square were used in the study. The palms were planted in a Tugbok clay loam (Alfisol) on a generally upland-flat and well-drained area. The palms were fertilized annually with $1.5 \mathrm{~kg}$ of ammonium sulfate and $2.0 \mathrm{~kg}$ potassium chloride (per tree) in blanket application.
Four coffee varieties formerly used in the varietal trial were used in this study to wit: Robusta-Philippines, Robusta-Ivory Coast, Excelsa and Arabica. They were planted in two rows in between coconut rows at $3 \times 3$ meters in a triangular pattern. Seventy-two hills of coffee completely surrounding 12 palms composed the experimental unit. This planting distance has 938 coffee trees per hectare of coconut. The coffee was also fertilized uniformly except in the seventh year when fertilization depended on the variety based on leaf analysis and growth or yield. The kind and rates of fertilizers are shown in Table 1.

Table 1. Fertilizers used for coffee intercrops (PCA-DRC, 1987 to 2001)

\begin{tabular}{|c|l|}
\hline $\begin{array}{c}\text { PERIOD OF } \\
\text { APPLICATION }\end{array}$ & \multicolumn{1}{c|}{$\begin{array}{c}\text { KIND AND } \\
\text { RATE/TREE }\end{array}$} \\
\hline $1^{\text {st }}$ six months & \\
\hline 3 months old & $150 \mathrm{~g} 14-14-14$ \\
\hline 6 months old & $150 \mathrm{~g} 14-14-14$ \\
\hline Year 1 & \\
\hline $1^{\text {st }}$ quarter & $150 \mathrm{~g} 14-14-14$ \\
\hline $2^{\text {nd }}-4^{\text {th }}$ quarter & $150 \mathrm{~g} \mathrm{Ammonium} \mathrm{sulfate}(\mathrm{AS})$ \\
\hline Year 2 & \\
\hline $1^{\text {st }} 6$ months & $400 \mathrm{~g} \mathrm{AS}$ \\
\hline $2^{\text {nd }} 6$ months & $250 \mathrm{~g} \mathrm{AS}+300 \mathrm{~g} \mathrm{KCl}$ \\
\hline Year 3-6 & $250 \mathrm{~g} \mathrm{AS}+300 \mathrm{~g} \mathrm{KCl} / 6$ months \\
\hline Year 7 & \\
\hline $1^{\text {st }} 6$ months & $250 \mathrm{~g} \mathrm{AS}+300 \mathrm{~g} \mathrm{KCl}$ \\
\hline $2^{\text {nd }} 6$ months & Rate depended on the variety \\
\hline Robusta $(\mathrm{Phil})$ & $175 \mathrm{~g} \mathrm{AS}+525 \mathrm{~g} \mathrm{KCl}+20 \mathrm{~g} \mathrm{Zn}{ }_{2} \mathrm{SO}_{4}$ \\
\hline Robusta $(\mathrm{IC})$ & $150 \mathrm{~g} \mathrm{AS}+450 \mathrm{~g} \mathrm{KCl}+20 \mathrm{~g} \mathrm{Zn}{ }_{2} \mathrm{SO}_{4}$ \\
\hline Excelsa & $200 \mathrm{~g} \mathrm{AS}+600 \mathrm{~g} \mathrm{KCl}+30 \mathrm{~g} \mathrm{Zn}{ }_{2} \mathrm{SO}_{4}$ \\
\hline Arabica & $150 \mathrm{~g} \mathrm{AS}+450 \mathrm{~g} \mathrm{KCl}+30 \mathrm{~g} \mathrm{Zn}{ }_{2} \mathrm{SO}_{4}$ \\
\hline Year $8-14$ & $250 \mathrm{~g} \mathrm{AS}+300 \mathrm{~g} \mathrm{KCl} / 6 \mathrm{months}$ \\
\hline
\end{tabular}




\subsection{Treatments}

The two treatments were: a) palms without CLP and b) palms with CLP at two replicates utilizing the four coffee varieties.

For the first five years, the coconuts were pruned from leaf rank 19 supporting the buko nuts down to the oldest leaf (maintaining 18 functional leaves on the upper crown region) by removal of leaves every 45 days at the same time of nut harvesting. Beginning the sixth year, the modified leaf pruning was followed, i.e. coconut leaves were pruned from leaf 23 (supporting the second oldest harvestable bunch) and the rest below, and thus, maintaining 22 living fronds.

\subsection{Experimental Design}

The treatments were arranged in a split plot design in a randomized complete block design with leaf pruning as the main plot and coffee variety as the subplot in two replications.

\subsection{Data Gathered}

For coconuts, number of nuts per tree, copra weight per nut and copra per tree and yearly leaf sampling for nutrient analysis were taken.

For coffee, berry yield data and leaf analysis were gathered yearly. Soil analysis was conducted at the end of the study.

\section{RESULTS AND DISCUSSION}

\subsection{Effect of Coconut Leaf Pruning (CLP), Coffee Variety and their Interaction on Coconut Yield}

Effect on Nut Yield. Results showed that nut yield per tree of palms with leaf pruning did not vary significantly with those without CLP in all the years of observation. However, palms with CLP had slightly lower nut yield per tree than those without CLP (Figure 1) despite modifying (reducing) the leaf pruning level from leaf rank 19 to leaf rank 23 in 1998. This general trend of slight nut yield reduction with CLP could be due to the fact that the pruned leaves were still functional.

The low nut yield obtained in 1998 and 1999 could be due to low rainfall that occurred in the later part of 1997 and earlier part of 1998 (Appendix Table 1).

Likewise, no interaction effect between coconut leaf pruning and coffee variety was noted on nut production.

Effect on Copra Weight. Although the

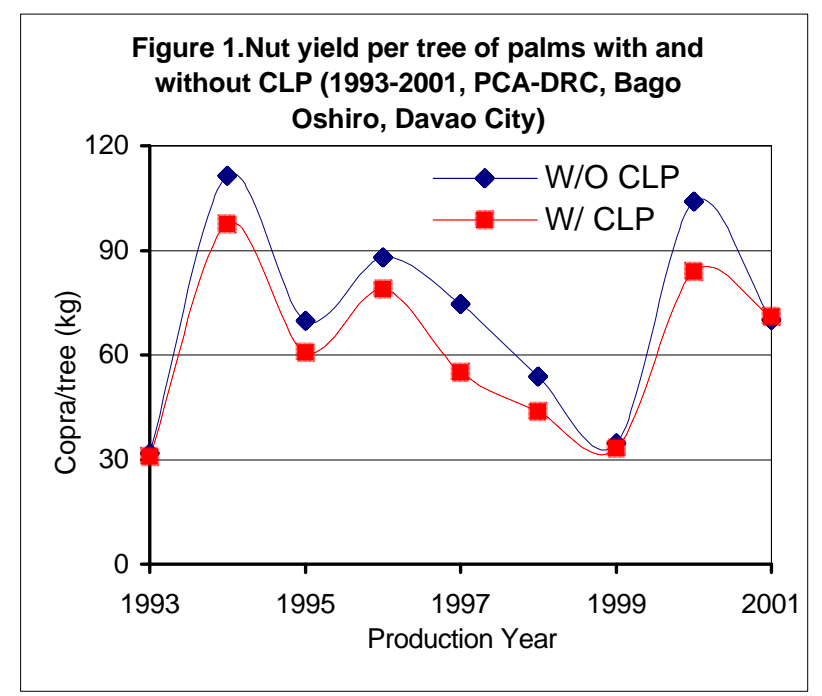

copra weight per nut of palms with and without leaf pruning treatments did not differ significantly throughout the duration of the study, it was improved with leaf pruning (Figure 2). It could be noted that there were considerable differences in copra weight per nut of palms with and without CLP in 1998 and 2000. Pruned palms produced heavier copra weight per nut than those without CLP indicating the positive influence of CLP on the palms particularly during long dry periods (El Niño/drought). The increase in copra weight per nut with CLP may be further explained by the principle of source - sink relationship as food nutrients are shared by fewer number of nuts, hence the nuts become bigger.

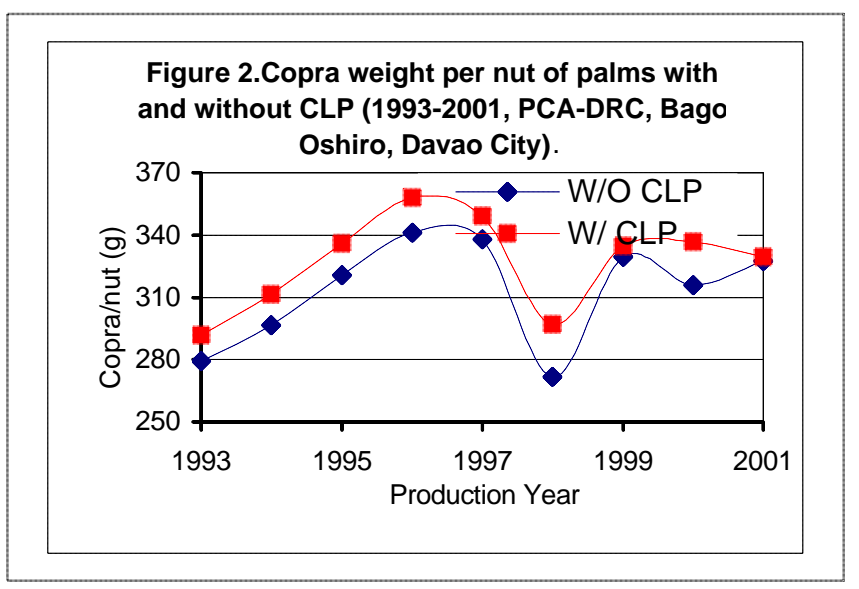


The consistent improvements in copra weight per nut of palms (by 1-9\%) was accompanied by improvement in the nutrition of palms particularly leaf $\mathrm{Cl}$ (Appendix Table 1). Earlier, Magat and Margate (1990) and Margate et. al (1978) obtained similar results on increased copra weight due to leaf $\mathrm{Cl}$. No interaction effect between coconut leaf pruning and coffee variety was noted on copra weight per nut.

Effect on Copra Yield. The copra yield per tree was not significantly affected by CLP (Appendix Table 1). However, pruned palms showed lower copra yield than those without LP due to reduction in nut yield (Figure 3) as copra per tree is a function of nut per tree multiplied by copra per nut. Likewise, no interaction effect between coconut leaf pruning and coffee variety was noted on copra yield per tree.

Results showed that maintaining 18-22 living leaves in the upper crown region can still provide palms with adequate physiological support for normal growth and production of palms. Likewise, leaf pruning gives additional sunlight for the intercrop grown under the coconut.

Further, Dolar (1960) also mentioned that the 10-12 older leaves of a mature coconut had little value as these leaves had already passed their productive stage hence, could be removed to divert nutrients and other growth factors to more physiologically active parts of the plant.

\subsection{Effect of Coconut Leaf Pruning, Coffee Variety and their Interaction on Yield of Coffee}

Coconut leaf pruning did not affect the green bean yield of coffee (Figure 4) indicating that coffee can withstand a shaded condition particularly under a 32-year old palms spaced at $8 \times 8$ meters square. This also suggests that sunlight transmission to coffee under the coconut-coffee planting system appears to be adequate since coffee needs 1000-3000 footcandles of light intensity. Light intensity under palms without CLP, it was 1750 foot-candles which is still within the range of coffee requirements, while for palms with CLP it was 4050 foot-candles. Moreover, much of the world's coffee is grown under shade trees which also protect against the overhead tropical sun (Vieth, 2001).

The response of coffee to coconut leaf pruning vary according to the varieties grown
(Appendix Table 2). Excelsa topped all other varieties in terms of green bean yield followed by the Robusta (Phil) and Robusta (IC) and Arabica in that order (Figure 5). The high yield obtained from Excelsa in terms of green bean yield could be due to its bigger and more berries borne in heavy clusters (149.5 g/100 fresh berries) which surpassed its yield potential of $1000 \mathrm{~kg} / \mathrm{ha}$ set by the Technical Coffee Committee (1976). This trend is consistent with that obtained by Margate et al (1997) on the same experimental materials in the previous varietal trial.

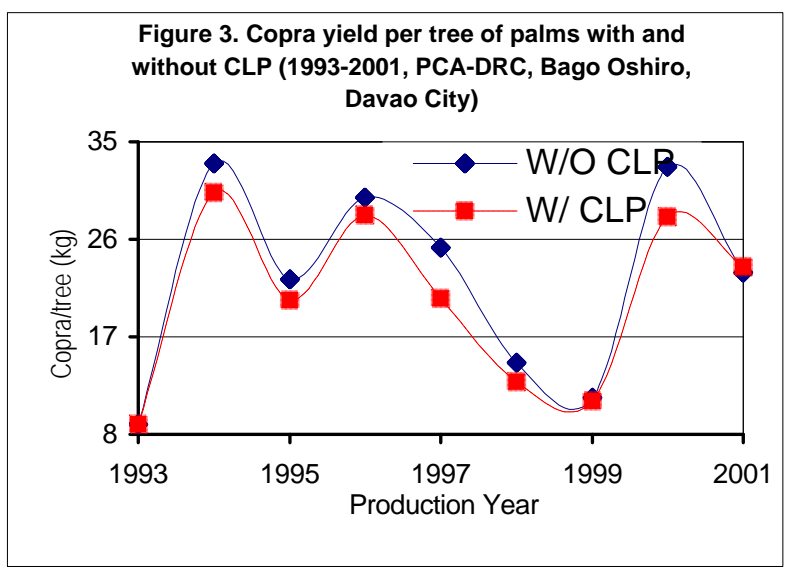



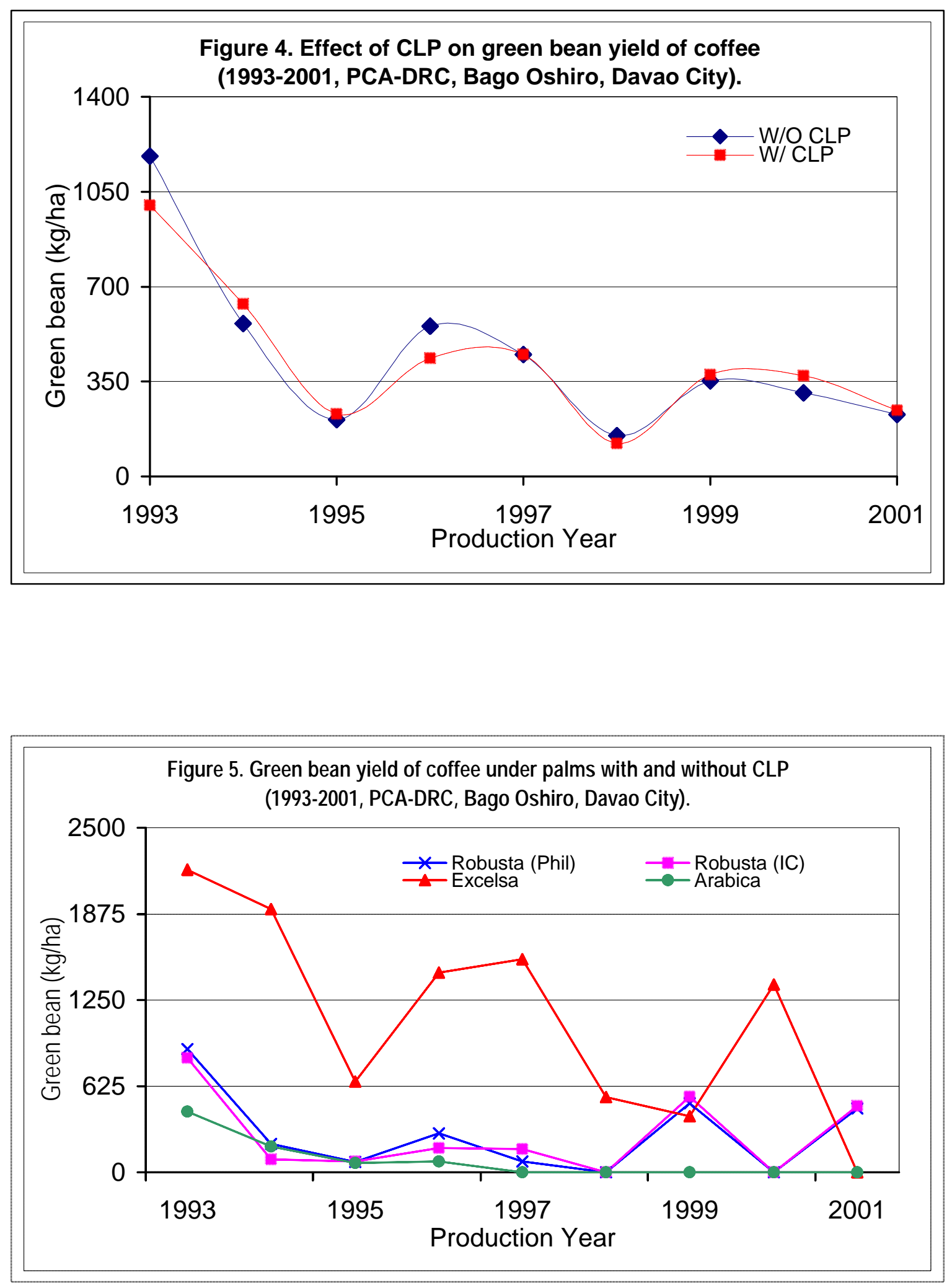
Excelsa could be grown on sea level to 600 meters above sea level and resists against drought and gives very high harvest (Teknotulong Aklat 1).

It was also observed that berry production of arabica was affected by a limiting rainfall. Its flowers were aborted at the onset of flower setting during the months of February and March in 1997 where rainfall ranged from 96.9-116.0 $\mathrm{mm}$ falling below the monthly average requirement of at least $158 \mathrm{~mm}$. The same trend was observed in 1998 where rainfall from January to April ranged from 8.5-44.2 mm only.

Arabica is usually associated with the tropical humid forest type at high altitudes. It grows best in an elevation of 600-1800 meters (1000-3000 feet) above sea level (Compton's Encyclopedia, 1973) where temperature ranges from $15.6-21.1{ }^{\circ} \mathrm{C}$ with a maximum of $23.9^{\circ} \mathrm{C}$ coupled with at least $1900 \mathrm{~mm}$ of annual rainfall (The Technical Committee, 1986). However, under Davao conditions at an elevation of 120 meters above sea level results showed that green bean yield ranged from 66 to $439.9 \mathrm{~kg} / \mathrm{ha}$. This suggests that it can withstand lower elevation and shading although reduction in yield occurred. Guyot et al. (1996) mentioned that shading virtually plays the same role as altitude in improving the yield and quality of arabica coffee. A full grown and well managed farm of arabica coffee in an open condition can yield about $500-1000 \mathrm{~kg} / \mathrm{ha}$ of green coffee beans (Cuevas and Creencia, 1974).

Robustas (Phil) and Robusta (IC) varieties showed similar green bean yield from 79.44 to $894.61 \mathrm{~kg} / \mathrm{ha}$ which were lower than the yield of Excelsa variety. Although their yield were very slightly higher, they did not vary significantly with arabica. Both were found growing best in warm tropical lowlands (CBFS, 1984).

Robusta has been introduced under warmer humid conditions. For robusta, it is essential to retain natural or artificial shade in conformity with the natural forest environment (De Rosayro, 2001). Likewise, no interaction effect between coconut leaf pruning and coffee variety was noted on the yield of coffee indicating that CLP had no adverse effect on the yield of coffee (Appendix Table 2).

\subsection{Effect of Coconut Leaf Pruning, Coffee Variety and their Interaction on Leaf Nutrient Content of Coconut and Coffee}

Coconut. Foliar analysis of the coconut showed that the leaf nutrient concentrations of $\mathrm{N}, \mathrm{P}, \mathrm{K}, \mathrm{Ca}, \mathrm{Mg}, \mathrm{Na}, \mathrm{Cl} \mathrm{S}$ and $\mathrm{B}$ were not significantly affected by leaf pruning (Appendix Table 3). This indicates that leaf pruning had no depressive effect on the nutrient status of palms. The regular blanket application of fertilizer provided adequate and balance nutrition of palms where concentrations of leaf nutrients were above the critical levels. The adequate nutrition of palms generally results in high yield of palms.

Though not significant, it could be observed that higher levels of $\mathrm{N}, \mathrm{P}, \mathrm{K}$ and $\mathrm{Cl}$ were noted in the pruned palms compared to unpruned palms (Figure 6). This observation supports the earlier claims of Das Cupta (1972) and Pereira (1978) that when leaves are removed, the photosynthetic efficiency of the remaining leaves is improved. Likewise, Delting et al., (1979) and Heichel and Turner (1985) added that mobile nutrients such as $\mathrm{N}, \mathrm{S}, \mathrm{K}$, and $\mathrm{Cl}$ as well as water become readily available to the remaining leaves. No interaction effect between CLP and coffee variety was noted on the leaf nutrient levels of coconut.

Coffee. Results showed that leaf nutrient concentrations of $\mathrm{N}, \mathrm{P}, \mathrm{K}, \mathrm{Ca}, \mathrm{Mg}, \mathrm{Na}, \mathrm{Cl} \mathrm{S}$, and, B did not differ signific antly among coffee

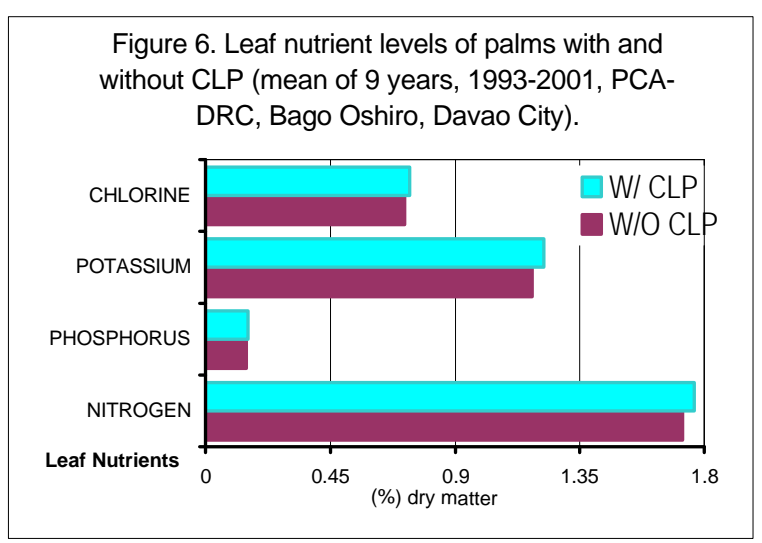


varieties with and without leaf pruning (Appendix Table 4). However, the different varieties of coffee responded differently to the fertilizer application. This is likely due to the differences in their nutritional requirements.

Leaf analysis revealed that Robusta (Phil), Robusta (IC) and Arabica had almost similar response to fertilization (or have similar leaf nutrient status) while the Excelsa was the opposite. The former varieties had higher values of N, K and B while Excelsa had lower values for these elements (Figure 7). On the other hand, the latter had higher levels of $\mathrm{Ca}, \mathrm{Cl}$ and $\mathrm{S}$, while the former were the opposite (Figure 8). Likewise, no interaction effect between coconut leaf pruning and coffee variety was noted on the nutrient contents of coffee.

Figure 7. Leaf nutrient levels of coffee under palms with and without CLP (mean of 9 years, 1993-2001, PCADRC, Bago Oshiro, Davao City).
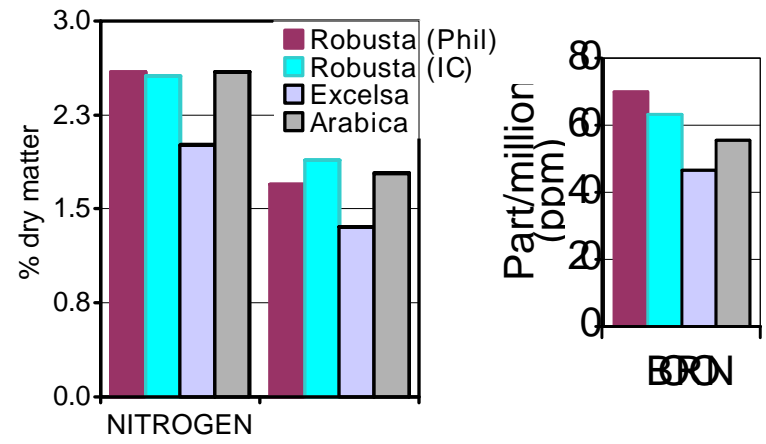

Martin-Prevel et al. (1987) citing the works of other authors mentioned that for some nutrients the same optimum levels apply to the crop species, while for the other nutrients there are varietal differences.

\subsection{Economics of Coconut Leaf Pruning in a Coconut+Coffee Cropping System}

Assuming the price of copra to be P10 per kilo and coffee at P50 per kilo, cash flow analysis using a discounted rate for eight years (Table 2)
Figure 8. Leaf nutrient levels of coffee under palms with and without CLP (mean of 9 years, 1993-2001, PCA-DRC, Bago Oshiro, Davao City)

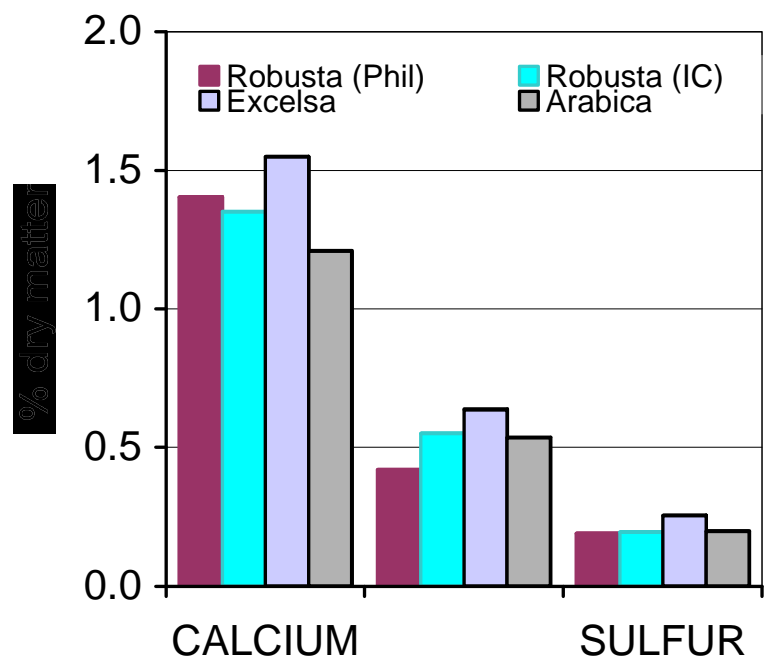

shows that for coffee intercropping under coconut, the no CLP treatment was more profitable than the CLP treatment. Although both had positive NPVs, the former had

acceptable BCR (1.0 or more) than the latter. On the otherhand, with CLP, lower BCR (0.95) was obtained although NPV was positive. The general rule is for a project to be economically viable, the NPV should be positive or equal to zero and the BCR to be 1.0 or better with IRR greater than the prevailing interest rates (Aragon, 2002).

Results generally indicate that CLP may not be an economically viable practice in coconutcoffee intercropping as it may just be an added expense since it did not increase coffee yield.

\section{CONCLUSION AND RECOMMENDATION}

The yield of coconut and coffee were not significantly affected by coconut leaf pruning (CLP) throughout the duration of the study. However, pruned palms had slightly lower nut and copra yield per palm while copra weight per nut improved with CLP. 
Coconut leaf pruning at leaf rank 19 or even at leaf rank 23 did not affect leaf nutrient status of palms and coffee. Yet higher levels of $\mathrm{N}, \mathrm{P}, \mathrm{K}$ and $\mathrm{Cl}$ are well noted on pruned palms. Foliar analysis also revealed that the robusta and arabica had more or less similar response to fertilization while the excelsa was the opposite.

Results of the study clearly showed that CLP at leaf rank 19 or 23 is still capable of providing adequate physiological support for normal growth and production of palms.

For the coffee intercrop, with required sunlight intensity of 1000-3000 foot-candles, the light transmission in this coconut + coffee cropping system ranging from 1750 foot-candles (palms without leaf pruning) to 4050 footcandles (palms with leaf pruning) was found within the essential range, and hence still very adequate for coffee production particularly under moderate elevations of 120-150 meters. Since, coffee can be grown profitably under shaded and no CLP condition, CLP may not be necessary for palms intended for coffee intercropping.

\section{ACKNOWLEDGEMENT}

The authors wish to extend their sincere gratitude to the following for their full support in the conduct of the study:

- The support staff of Agronomy and Soils Division of Davao Research Center for their apt assistance in the fertilizer application, data collection and consolidation.

- The staff of the Plant Tissue Analysis Laboratory lead by Ms. Carmelita D. Pabustan for the leaf analysis.

- Special thanks to DM Romero C. Blancaver and PCAs top management for their much needed administrative and financial support.

\section{LITERATURE CITED}

Aragon, C.T. 2002. Cost and return analysis of outputs of PCA mature technologies and coconut-based farming systems. Paper presented at the workshop on TechnoDemo of PCA Mature Technologies in the Integrated Farming Systems Development Sites. PCA-CETC, Bago Oshiro, Davao City.

Bailey, P. 1977. Effects of artificial defoliation on coconut yield in Papua New Guinea. Papua New Guinea Agricultural Journal. 28(2/3/4):39-45.

Calvez, C. 1976. Influences on oil palm yield of pruning at different levels. Oleagineux. 31(2):57-58.

Compton's Encyclopedia. 1973 ed. 5:427-430.

Coconut-Based Farming System - Status and Prospects. 1984. A Joint Publication of FSSRI, UPLB- College Laguna and PCA, Diliman, Quezon City. p. 147.

Cuevas, S.E. and R.P. Creencia. 1974. Coffee growing and production. Extension Circular No. 4. Department of Horticulture. UPLB, College of Agriculture. 28 pp. Mimeo.

Das Cupta, D.K. 1972. Effects of decapitulation, defoliation and removing part of the root and shoot on subsequent growth of sugar beet. J. Exp. Bot. 23(94):93-102.

De Geus, J.G. 1967. Fertilizer Guide for Tropical and Subtropical Farming Centre d' etude de L'Azote, Zurich. p. 391. In: Coconut-Based Farming System - Status and Prospects. 1984. A Joint Publication of FSSRI, UPLB- College Laguna and PCA, Diliman, Quezon City. p. 47. 
Delting, J.K. 1979. Net photosynthesis, root respiration and regrowth of Boutelova Gracilis following simulated grazing. Oecologia. 41:127-134.

De Rosayro, R.A. 2001. Unasylva- No. 89 Diversification forestry in coffee-producing countries. Paper of the FAO Forestry and Forest Industries Division at (www.fao.org).

Dolar, S.G. 1961. The environmental factors and cultural practices affecting production of coconut. M.S. Thesis Cornel University, Ithaca, New York.

Gifford, R.M. and L.T. Evans. 1981. Photosynthesis, carbon partitioning, and yield. Annual Review. Plant Physiology 32:485-509.

Guyot, B, D Guele, J.C. Manez, J.J. Perriot,, J. Gironn and L.Villain. 1996. Influencia de la altitud y de la sombra sabre la calidad de los café's arabica. Plantation, Recherché, Developpement. pp. 281-283.

Heichel, G.H. and N.C. Turner. 1985. Carbon dioxide assimilation of primary and regrowth foliages of old maple and red oak. Response to defoliation. Oecologia. 57:1419.

Magat, S.S. and R.Z. Margate. 1990. The chlorine needs of coconut. CORD. 6 (1) 30 51 .

Margate, R.Z., S.S. Magat, L.M. Alforja and J.A. Habana. 1979 A long-term $\mathrm{KCl}$ fertilization study of bearing coconuts in an inland upland area of Davao. Oleagineux. 34(5): 235-240.

J.N. Maravilla, M.N. Eroy and L.H. Canja. 1997. Growth and yield performance of four coffee varieties in coconut-based cropping system in an inland-upland area of Davao. DA-BAR National Research Symposium, Diliman, Quezon City.

Martin-Prevel, P. J. Gograid, P. Gutier. 1987. Plant analysis - as a guide to nutrient requirement of temperate and tropical crops. $722 \mathrm{p}$.

Pereira, A.S.R. 1978. Effect of leaf removal in the yield components of sunflower. Netherlands Journal of Agricultural Science. 26:133-144.

Perfecto, I., R. Rice, R. Greenberg and M. Van der Voort. 1996. Shade coffee: A disappearing refuge for biodiversity. Bioscience. 46(8):598-608.

Teknotulong Aklat 1. 2001. @ (www.dost.gov.ph).

The Technical Committee. 1976. The Philippine Recommends for Coffee pp. 76.

The Technical Committee . 1986. Environmental adaptation of crops. PCARRD and Soil Management Support Services, Soil Conservation Service, USDA. Los Baños, Laguna, Philippines. PCARRD Book Series 37. pp. 48-61.

Vieth, R. 2001. Coffee - Avocado, minor, subtropical and soils/water. Ventura Country at (www.ceventura.ucdavic.edu)

(www.geocities.com). 2001. Coffee contact - the basics.

(www.wri.org). 2000. Trouble brewing: The changing face of coffee production. Global Trends. World Resources Institute, Washington, DC. USA.

(www.seattleaudubon.org). 2002. The problem with coffee. Northwest Shade Coffee Campaign. 
Appendix Table 1. Annual nut and copra yield of palms with and without coconut leaf pruning I ntercropped with coffee (PCA-DRC, Bago Oshiro, Davao City).

\begin{tabular}{|c|c|c|c|c|c|c|c|c|c|}
\hline \multirow{2}{*}{ TREATMENT } & 1993 & 1994 & 1995 & 1996 & 1997 & 1998 & 1999 & 2000 & 2001 \\
\hline & \multicolumn{9}{|c|}{ NUT/ TREE (NO.) } \\
\hline \multicolumn{10}{|l|}{ Coconut Leaf Pruning (CLP) } \\
\hline $\mathrm{W} / \mathrm{O} \mathrm{LP}$ & 31.8 & 111.4 & 69.7 & 88.0 & 74.7 & 53.8 & 34.8 & 103.9 & 70.1 \\
\hline W/ LP & 30.8 & 97.5 & 60.7 & 78.9 & 54.9 & 43.7 & 33.2 & 83.8 & 71.1 \\
\hline \multicolumn{10}{|l|}{ Varieties (V) } \\
\hline Robusta (Phil) & 31.6 & 103.3 & 66.6 & 84.1 & 71.4 & 48.3 & 37.0 & 93.9 & 79.1 \\
\hline Robusta (IC) & 29.4 & 109.7 & 61.3 & 86.8 & 65.3 & 48.4 & 32.6 & 99.4 & 68.2 \\
\hline Excelsa & 30.5 & 104.7 & 67.5 & 80.0 & 63.8 & 48.0 & 33.6 & 88.7 & 69.2 \\
\hline Arabica & 33.7 & 100.2 & 65.6 & 83.0 & 66.7 & 50.4 & 32.7 & 93.5 & 65.8 \\
\hline Stat sig. Coconut Leaf Pruning (CLP) & Ns & Ns & ns & ns & ns & ns & ns & ns & ns \\
\hline Variety $(\mathrm{V})$ & Ns & Ns & ns & ns & ns & ns & ns & ns & ns \\
\hline CLPXV & Ns & Ns & ** & ns & ns & ns & ns & ns & ns \\
\hline CV (\%) CLP & 41.4 & 5.7 & 19.3 & 5.5 & 4.1 & 1.9 & 29.7 & 32.7 & 9.1 \\
\hline $\mathrm{V}$ & 20.5 & 9.4 & 4.1 & 12.0 & 8.8 & 19.3 & 24.5 & 13.4 & 9.6 \\
\hline \multicolumn{10}{|c|}{ COPRA/ NUT (g) } \\
\hline \multicolumn{10}{|l|}{ Coconut Leaf Pruning (CLP) } \\
\hline W/O LP & 279.4 & 296.5 & 320.8 & 341.1 & 337.7 & 271.6 & 329.3 & 315.9 & 327.6 \\
\hline W/ LP & 291.6 & 311.5 & 336.0 & 357.9 & 349.1 & 296.9 & 334.5 & 336.8 & 329.6 \\
\hline \multicolumn{10}{|l|}{ Varieties (V) } \\
\hline Robusta (Phil) & 291.9 & 317.4 & 334.9 & 349.3 & 346.7 & 302.3 & 342.5 & 334.0 & 339.3 \\
\hline Robusta (IC) & 278.8 & 295.1 & 318.3 & 343.7 & 343.5 & 276.3 & 325.9 & 321.0 & 331.7 \\
\hline Excelsa & 284.7 & 301.3 & 327.8 & 357.5 & 348.6 & 285.3 & 325.6 & 329.8 & 319.6 \\
\hline Arabica & 286.6 & 302.3 & 332.6 & 347.6 & 335.0 & 273.0 & 333.6 & 320.7 & 323.7 \\
\hline Stat sig. Coconut Leaf Pruning (CLP) & Ns & ns & ns & ns & ns & ns & ns & $\mathrm{ns}$ & ns \\
\hline Variety $(\mathrm{V})$ & Ns & ns & ns & ns & ns & ns & ns & ns & ns \\
\hline CLPxV & Ns & ns & ns & ns & ns & ns & ns & ns & ns \\
\hline CV (\%) CLP & 13.3 & 2.0 & 11.0 & 3.6 & 2.4 & 1.9 & 8.1 & 7.3 & 3.1 \\
\hline $\mathrm{V}$ & 1.4 & 5.9 & 6.9 & 6.9 & 2.8 & 4.1 & 5.1 & 5.9 & 3.9 \\
\hline \multicolumn{10}{|c|}{ COPRA/ TREE (Kg) } \\
\hline \multicolumn{10}{|l|}{ Coconut Leaf Pruning (CLP) } \\
\hline W/O LP & 9.0 & 33.0 & 22.3 & 29.8 & 25.2 & 14.6 & 11.4 & 32.7 & 22.9 \\
\hline $\mathrm{W} / \mathrm{LP}$ & 8.9 & 30.3 & 20.4 & 28.2 & 20.6 & 12.8 & 11.1 & 28.1 & 23.5 \\
\hline \multicolumn{10}{|l|}{ Varieties (V) } \\
\hline Robusta (Phil) & 9.2 & 32.5 & 22.2 & 28.9 & 24.6 & 14.2 & 12.7 & 30.3 & 26.7 \\
\hline Robusta (IC) & 8.2 & 32.4 & 19.4 & 29.7 & 22.4 & 13.4 & 10.6 & 31.9 & 22.6 \\
\hline Excelsa & 8.6 & 31.5 & 22.0 & 28.6 & 22.2 & 13.5 & 10.9 & 29.3 & 22.2 \\
\hline Arabica & 9.7 & 30.3 & 21.8 & 28.8 & 22.4 & 13.7 & 10.9 & 29.9 & 21.3 \\
\hline Stat sig. Coconut Leaf Pruning (CLP) & Ns & ns & ns & ns & ns & ns & ns & ns & ns \\
\hline Variety $(\mathrm{V})$ & Ns & ns & ns & ns & ns & ns & ns & ns & ns \\
\hline CLPXV & * & ns & ns & ns & ns & ns & ns & ns & ns \\
\hline CV (\%) CLP & 52.4 & 3.7 & 29.1 & 1.3 & 1.1 & 3.3 & 39.6 & 25.6 & 5.3 \\
\hline $\mathrm{V}$ & 19.7 & 10.0 & 7.9 & 7.7 & 9.1 & 17.3 & 25.9 & 12.1 & 11.5 \\
\hline
\end{tabular}




\begin{tabular}{|c|c|c|c|c|c|c|c|c|c|}
\hline \multicolumn{10}{|c|}{$\begin{array}{l}\text { Appendix Table 2. Green bean yield of coffee under palms with and without coconut leaf pruning } \\
\text { (1993-2001, PCA-DRC, Bago Oshiro, Davao City) }\end{array}$} \\
\hline \multirow{2}{*}{ TREATMENT } & 1993 & 1994 & 1995 & 1996 & 1997 & 1998 & 1999 & 2000 & 2001 \\
\hline & \multicolumn{9}{|c|}{ GREEN BEAN YIELD (kg/ha) } \\
\hline \multicolumn{10}{|l|}{ Coconut Leaf Pruning (CLP) } \\
\hline W/O LP & $1181.18^{a}$ & 564.65 & 208.61 & 554.86 & 448.60 & 149.59 & 353.29 & 309.42 & 228.41 \\
\hline W/ LP & $999.08^{b}$ & 635.59 & 230.94 & 436.10 & 448.62 & 121.95 & 374.66 & 371.52 & 243.07 \\
\hline \multicolumn{10}{|l|}{ Varieties (V) } \\
\hline Robusta (Phil) & $894.61^{b}$ & $205.43^{b}$ & $76.90^{b}$ & $279.69^{b}$ & $79.44^{\mathrm{bc}}$ & $0.00^{b}$ & $499.93^{a}$ & $0.00^{b}$ & $463.02^{\mathrm{a}}$ \\
\hline Robusta (IC) & $828.31^{b c}$ & $94.20^{b}$ & $80.22^{b}$ & $176.67^{b}$ & $168.11^{b}$ & $0.00^{b}$ & $549.75^{a}$ & $0.00^{b}$ & $479.94^{\text {a }}$ \\
\hline Excelsa & $2197.69^{a}$ & $1911.31^{\mathrm{a}}$ & $655.93^{a}$ & $1447.49^{\mathrm{a}}$ & $1546.87^{a}$ & $543.09^{a}$ & $406.24^{\mathrm{a}}$ & $1361.87^{\mathrm{a}}$ & $0.00^{b}$ \\
\hline Arabica & $439.90^{c}$ & $189.54^{b}$ & $66.05^{b}$ & $78.08^{b}$ & $0.00^{c}$ & $0.00^{b}$ & $0.00^{b}$ & $0.00^{b}$ & $0.00^{b}$ \\
\hline $\begin{array}{l}\text { Stat. Sig. Coconut Leaf Pruning } \\
\text { (CLP) }\end{array}$ & $*$ & ns & ns & ns & ns & ns & ns & ns & ns \\
\hline Variety $(\mathrm{V})$ & $* *$ & $* *$ & $* *$ & $* *$ & $* *$ & $* *$ & $*$ & $* *$ & $* *$ \\
\hline CLPxV & ns & ns & ns & $* *$ & ns & ns & ns & ns & ns \\
\hline CV $(\%)$ CLP & 0.58 & & 24.31 & 35.74 & 30.50 & 47.57 & 15.18 & 12.49 & 18.98 \\
\hline $\mathrm{V}$ & 21.03 & & 35.98 & 14.59 & 26.28 & 33.64 & 46.06 & 43.24 & 18.84 \\
\hline \multicolumn{10}{|l|}{$\begin{array}{ll}* & \text { Highly significant at } 1 \% \\
* & \text { Significant at } 5 \% \\
\text { Ns } & \text { Not significant }\end{array}$} \\
\hline
\end{tabular}


Appendix Table 3. Mean nutrient levels of coconut leaves (\%) with and without coconut leaf pruning intercropped with coffee

(1993-2001, PCA-DRC, Bago Oshiro, Davao City)

\begin{tabular}{|l|c|c|c|c|c|c|c|c|c|c|}
\hline \hline TREATMENT & N & P & K & Ca & Mg & Na & Cl & \multicolumn{1}{|c|}{ S } & B(ppm) \\
\hline Coconut Leaf Pruning (CLP) \\
\hline W/O LP & 1.722 & 0.147 & 1.178 & 0.412 & 0.226 & 0.096 & 0.717 & 0.161 & 8.2 \\
\hline W/ LP & 1.764 & 0.154 & 1.221 & 0.402 & 0.217 & 0.086 & 0.727 & 0.165 & 8.5 \\
\hline Varieties (V) & 1.734 & 0.149 & 1.166 & 0.412 & 0.222 & 0.081 & 0.746 & 0.161 & 8.5 \\
\hline Robusta (Phil) & 1.755 & 0.150 & 1.241 & 0.408 & 0.214 & 0.098 & 0.752 & 0.166 & 8.4 \\
\hline Robusta (IC) & 1.768 & 0.151 & 1.209 & 0.411 & 0.231 & 0.097 & 0.733 & 0.166 & 8.1 \\
\hline Excelsa & 1.745 & 0.15 & 1.172 & 0.397 & 0.219 & 0.088 & 0.670 & 0.159 & 8.4 \\
\hline Arabica &
\end{tabular}

Appendix Table 4. Mean nutrient levels of coffee leaves under palms with and without leaf pruning (1992-2001, PCA-DRC, Bago Oshiro, Davao City

\begin{tabular}{|l|c|c|c|c|c|c|c|c|}
\hline \hline TREATMENT & N & P & K & Ca & Cl & S & B (ppm) \\
\hline Coconut Leaf Pruning (CLP) \\
\hline W/O LP & 2.462 & 0.125 & 1.733 & 1.373 & 0.530 & 0.207 & 57.1 \\
\hline W/ LP & 2.413 & 0.129 & 1.625 & 1.450 & 0.540 & 0.206 & 61.3 \\
\hline Varieties (V) & 2.592 & 0.127 & 1.693 & 1.405 & 0.419 & 0.190 & 70.4 \\
\hline Robusta (Phil) & 2.558 & 0.128 & 1.887 & 1.344 & 0.550 & 0.194 & 63.6 \\
\hline Robusta (IC) & 2.008 & 0.129 & 1.353 & 1.628 & 0.636 & 0.255 & 47.2 \\
\hline Excelsa & 2.592 & 0.124 & 1.784 & 1.160 & 0.535 & 0.198 & 55.5 \\
\hline Arabica
\end{tabular}


Appendix Table 5. Financial cash flow analysis of coconut + coffee agro-ecosystem under leaf pruning conditions

\begin{tabular}{|c|c|c|c|c|c|c|c|c|c|}
\hline YEAR & 1993 & 1994 & 1995 & 1996 & 1997 & 1998 & 1999 & 2000 & 2001 \\
\hline \multicolumn{10}{|l|}{ A. W/O CLP } \\
\hline \multicolumn{10}{|l|}{ GROSS BENEFITS } \\
\hline Sales from Coffee & $76,776.70$ & $36,702.25$ & $13,559.65$ & $36,065.90$ & $29,159.00$ & $9,723.35$ & $22,963.85$ & $20,112.30$ & $14,846.65$ \\
\hline Sales from Copra & $13,962.00$ & $51,448.80$ & $34,819.20$ & $46,550.40$ & $39,312.00$ & $22,744.80$ & $17,799.60$ & $50,949.60$ & $35,739.60$ \\
\hline TOTAL GROSS BENEFITS & PHP 90,738.70 & $88,151.05$ & $48,378.85$ & $82,616.30$ & $68,471.00$ & $32,468.15$ & $40,763.45$ & $71,061.90$ & $50,586.25$ \\
\hline \multicolumn{10}{|l|}{ GROSS COSTS } \\
\hline Operating and Maintenance Expenses & $23,170.40$ & $30,608.85$ & $26,095.41$ & $29,702.76$ & $27,458.60$ & $23,017.79$ & $22,313.49$ & $30,228.82$ & $26,345.31$ \\
\hline TOTAL GROSS COSTS & PHP 23,170.40 & $30,608.85$ & $26,095.41$ & $29,702.76$ & $27,458.60$ & $23,017.79$ & $22,313.49$ & $30,228.82$ & $26,345.31$ \\
\hline NET BENEFIT & PHP $67,568.30$ & $57,542.20$ & $22,283.44$ & $52,913.54$ & $41,012.40$ & $9,450.36$ & $18,449.96$ & $40,833.08$ & $24,240.94$ \\
\hline NPV (12\%) PhP & PHP 217,328.09 & & & & & & & & \\
\hline BCR & 1.53 & & & & & & & & \\
\hline \multicolumn{10}{|l|}{ IRR } \\
\hline \multicolumn{10}{|l|}{ B. W/ CLP } \\
\hline \multicolumn{10}{|l|}{ GROSS BENEFITS } \\
\hline Sales from Copra & $13,899.60$ & $47,330.40$ & $31,746.00$ & $43,992.00$ & $32,058.00$ & $20,014.80$ & $17,300.40$ & $43,758.00$ & $36,597.60$ \\
\hline Sales from Pruned Leaves & $7,488.00$ & $9,984.00$ & $9,984.00$ & $9,984.00$ & $9,984.00$ & $9,984.00$ & $9,984.00$ & $9,984.00$ & $9,984.00$ \\
\hline TOTAL GROSS BENEFITS & PHP $86,327.80$ & $98,627.75$ & $56,741.10$ & $82,322.50$ & $71,202.30$ & $37,925.55$ & $51,637.30$ & $77,890.80$ & $62,381.15$ \\
\hline \multicolumn{10}{|l|}{ GROSS COSTS } \\
\hline Operating and Maintenance Expenses & $23,154.70$ & $30,378.19$ & $26,077.44$ & $29,672.40$ & $26,373.12$ & $23,035.65$ & $22,938.06$ & $29,221.02$ & $27,302.47$ \\
\hline TOTAL GROSS COSTS & PHP 23,154.70 & $30,378.19$ & $26,077.44$ & $29,672.40$ & $26,373.12$ & $23,035.65$ & $22,938.06$ & $29,221.02$ & $27,302.47$ \\
\hline NET BENEFIT & PHP 63,173.10 & $68,249.56$ & $30,663.66$ & $52,650.10$ & $44,829.18$ & $14,889.90$ & $28,699.24$ & $48,669.78$ & $35,078.68$ \\
\hline NPV (12\%) PhP & PHP 244,368.24 & & & & & & & & \\
\hline BCR & 1.73 & & & & & & & & \\
\hline IRR & & & & & & & & & \\
\hline
\end{tabular}


Appendix Table 6. Sensitivity analysis of coconut + coffee agro-ecosystem under leaf pruning conditions (20\% decrease in sales)

\begin{tabular}{|c|c|c|c|c|c|c|c|c|c|}
\hline YEAR & 1993 & 1994 & 1995 & 1996 & 1997 & 1998 & 1999 & 2000 & 2001 \\
\hline \multicolumn{10}{|l|}{ A. W/O CLP } \\
\hline \multicolumn{10}{|l|}{ GROSS BENEFITS } \\
\hline Sales from Coffee & $61,421.36$ & $29,361.80$ & $10,847.72$ & $28,852.72$ & $23,327.20$ & $7,778.68$ & $18,371.08$ & $16,089.84$ & $11,877.32$ \\
\hline Sales from Copra & $11,169.60$ & $41,159.04$ & $27,855.36$ & $37,240.32$ & $31,449.60$ & $18,195.84$ & $14,239.68$ & $40,759.68$ & $28,591.68$ \\
\hline TOTAL GROSS BENEFITS & PHP 72,590.96 & $\mathbf{7 0 , 5 2 0 . 8 4}$ & 38,703.08 & $66,093.04$ & $54,776.80$ & $25,974.52$ & $32,610.76$ & $56,849.52$ & $40,469.00$ \\
\hline \multicolumn{10}{|l|}{ GROSS COSTS } \\
\hline $\begin{array}{l}\text { Operating and } \\
\text { Expenses }\end{array}$ & $23,170.40$ & $30,608.85$ & $26,095.41$ & $29,702.76$ & $27,458.60$ & $23,017.79$ & $22,313.49$ & $30,228.82$ & $26,345.31$ \\
\hline TOTAL GROSS COSTS & PHP 23,170.40 & $30,608.85$ & $26,095.41$ & 29,702.76 & $27,458.60$ & 23,017.79 & $22,313.49$ & 30,228.82 & $26,345.31$ \\
\hline NET BENEFIT & PHP 49,420.56 & 39,911.99 & $12,607.67$ & \begin{tabular}{|c|}
$36,390.28$ \\
\end{tabular} & $27,318.20$ & $2,956.73$ & $10,297.27$ & $26,620.70$ & $14,123.69$ \\
\hline NPV (12\%) PhP & PHP 145,545.48 & & & & & & & & \\
\hline BCR & 1.03 & & & & & & & & \\
\hline \multicolumn{10}{|l|}{ IRR } \\
\hline \multicolumn{10}{|l|}{ B. W/ CLP } \\
\hline Sales from Copra & $11,119.68$ & $37,864.32$ & $25,396.80$ & $35,193.60$ & $25,646.40$ & $16,011.84$ & $13,840.32$ & $35,006.40$ & $29,278.08$ \\
\hline Sales from Pruned Leaves & $5,990.40$ & $7,987.20$ & $7,987.20$ & $7,987.20$ & $7,987.20$ & $7,987.20$ & $7,987.20$ & $7,987.20$ & $7,987.20$ \\
\hline TOTAL GROSS BENEFITS & PHP 69,062.24 & $78,902.20$ & 45,392.88 & $65,858.00$ & $56,961.84$ & $30,340.44$ & $41,309.84$ & $62,312.64$ & $49,904.92$ \\
\hline \multicolumn{10}{|l|}{ GROSS COSTS } \\
\hline $\begin{array}{l}\text { Operating and } \\
\text { Expenses }\end{array}$ & $23,154.70$ & 30,378.19 & $26,077.44$ & $29,672.40$ & $26,373.12$ & $23,035.65$ & $22,938.06$ & $29,221.02$ & $27,302.47$ \\
\hline TOTAL GROSS COSTS & PHP 23,154.70 & 30,378.19 & $26,077.44$ & $29,672.40$ & $26,373.12$ & $23,035.65$ & $22,938.06$ & $29,221.02$ & $27,302.47$ \\
\hline NET BENEFIT & PHP 45,907.54 & $48,524.01$ & $19,315.44$ & $36,185.60$ & 30,588.72 & 7,304.79 & $18,371.78$ & $33,091.62$ & $22,602.45$ \\
\hline NPV (12\%) PhP & PHP $167,300.85$ & & & & & & & & \\
\hline
\end{tabular}


Appendix Table 7. Cash flow analysis of coconut + coffee agro-ecosystem under leaf pruning conditions ( $20 \%$ increase in operations \& maintenance costs)

\begin{tabular}{|c|c|c|c|c|c|c|c|c|c|}
\hline YEAR & 1993 & 1994 & 1995 & 1996 & 1997 & 1998 & 1999 & 2000 & 2001 \\
\hline \multicolumn{10}{|l|}{ A. W/O CLP } \\
\hline \multicolumn{10}{|l|}{ GROSS BENEFITS } \\
\hline Sales from Coffee & $76,776.70$ & $36,702.25$ & $13,559.65$ & $36,065.90$ & $29,159.00$ & $9,723.35$ & $22,963.85$ & $20,112.30$ & $14,846.65$ \\
\hline Sales from Copra & $13,962.00$ & $51,448.80$ & $34,819.20$ & $46,550.40$ & $39,312.00$ & $22,744.80$ & $17,799.60$ & $50,949.60$ & $35,739.60$ \\
\hline TOTAL GROSS BENEFITS & PHP 90,738.70 & $88,151.05$ & $48,378.85$ & $82,616.30$ & $68,471.00$ & $32,468.15$ & $40,763.45$ & $71,061.90$ & $50,586.25$ \\
\hline \multicolumn{10}{|l|}{ GROSS COSTS } \\
\hline $\begin{array}{l}\text { Operating and Maintenance } \\
\text { Expenses }\end{array}$ & $27,804.48$ & $36,730.62$ & $31,314.49$ & $35,643.31$ & $32,950.32$ & $27,621.35$ & $26,776.19$ & $36,274.58$ & $31,614.37$ \\
\hline TOTAL GROSS COSTS & PHP 27,804.48 & $36,730.62$ & $31,314.49$ & $35,643.31$ & $32,950.32$ & $27,621.35$ & $26,776.19$ & $36,274.58$ & $31,614.37$ \\
\hline NET BENEFIT & \begin{tabular}{|l|} 
PHP 62,934.22 \\
\end{tabular} & $51,420.43$ & $17,064.36$ & $46,972.99$ & $35,520.68$ & $4,846.80$ & $13,987.26$ & $34,787.32$ & $18,971.88$ \\
\hline NPV $(12 \%)$ PhP & PHP 189,011.10 & & & & & & & & \\
\hline BCR & 1.11 & & & & & & & & \\
\hline \multicolumn{10}{|l|}{ IRR } \\
\hline \multicolumn{10}{|l|}{ B. W/ CLP } \\
\hline Sales from Coffee & $64,940.20$ & $41,313.35$ & $15,011.10$ & $28,346.50$ & $29,160.30$ & $7,926.75$ & $24,352.90$ & $24,148.80$ & $15,799.55$ \\
\hline Sales from Copra & $13,899.60$ & $26,440.54$ & $9,607.10$ & $18,141.76$ & $18,662.59$ & $5,073.12$ & $15,585.86$ & $15,455.23$ & $10,111.71$ \\
\hline Sales from Pruned Leaves & $7,488.00$ & $9,984.00$ & $9,984.00$ & $9,984.00$ & $9,984.00$ & $9,984.00$ & $9,984.00$ & $9,984.00$ & $9,984.00$ \\
\hline TOTAL GROSS BENEFITS & PHP 86,327.80 & $\mathbf{7 7 , 7 3 7 . 8 9}$ & $34,602.20$ & $56,472.26$ & $57,806.89$ & $22,983.87$ & $49,922.76$ & $49,588.03$ & $35,895.26$ \\
\hline \multicolumn{10}{|l|}{ GROSS COSTS } \\
\hline $\begin{array}{l}\text { Operating and Maintenance } \\
\text { Expenses }\end{array}$ & $27,785.64$ & $36,453.83$ & $31,292.93$ & $35,606.88$ & $31,647.74$ & $27,642.78$ & $27,525.67$ & $35,065.22$ & $32,762.96$ \\
\hline TOTAL GROSS COSTS & PHP 27,785.64 & $36,453.83$ & $31,292.93$ & $35,606.88$ & $31,647.74$ & $27,642.78$ & $27,525.67$ & $35,065.22$ & $32,762.96$ \\
\hline NET BENEFIT & 58542.16 & 41284.07 & 3309.28 & 20865.38 & 26159.15 & -4658.91 & 22397.08 & 14522.81 & 3132.30 \\
\hline NPV (18\%) PhP & PHP 130,406.41 & & & & & & & & \\
\hline BCR & 0.77 & & & & & & & & \\
\hline
\end{tabular}


Appendix Table 8. Cash flow analysis of coconut+coffee agro-ecosystem under leaf pruning conditions (simultaneous occurrence)

\begin{tabular}{|c|c|c|c|c|c|c|c|c|c|}
\hline YEAR & 1993 & 1994 & 1995 & 1996 & 1997 & 1998 & 1999 & 2000 & 2001 \\
\hline \multicolumn{10}{|l|}{ A. W/O CLP } \\
\hline \multicolumn{10}{|l|}{ GROSS BENEFITS } \\
\hline Sales from Coffee & $61,421.36$ & $29,361.80$ & $10,847.72$ & $28,852.72$ & $23,327.20$ & $7,778.68$ & $18,371.08$ & $16,089.84$ & $11,877.32$ \\
\hline Sales from Copra & $11,169.60$ & $41,159.04$ & $27,855.36$ & $37,240.32$ & $31,449.60$ & $18,195.84$ & $14,239.68$ & $40,759.68$ & $28,591.68$ \\
\hline TOTAL GROSS BENEFITS & PHP 72,590.96 & $70,520.84$ & $38,703.08$ & $66,093.04$ & $54,776.80$ & $25,974.52$ & $32,610.76$ & $56,849.52$ & $40,469.00$ \\
\hline \multicolumn{10}{|l|}{ GROSS COSTS } \\
\hline $\begin{array}{l}\text { Operating and Maintenance } \\
\text { Expenses }\end{array}$ & $27,804.48$ & $36,730.62$ & $31,314.49$ & $35,643.31$ & $32,950.32$ & $27,621.35$ & $26,776.19$ & $36,274.58$ & $31,614.37$ \\
\hline TOTAL GROSS COSTS & PHP 27,804.48 & $36,730.62$ & $31,314.49$ & $35,643.31$ & $32,950.32$ & $27,621.35$ & $26,776.19$ & $36,274.58$ & $31,614.37$ \\
\hline NET BENEFIT & PHP 44,786.48 & $33,790.22$ & $7,388.59$ & $30,449.73$ & $21,826.48$ & $-1,646.83$ & $5,834.57$ & $20,574.94$ & $8,854.63$ \\
\hline NPV (12\%) PhP & PHP 117,228.49 & & & & & & & & \\
\hline BCR & 0.69 & & & & & & & & \\
\hline \multicolumn{10}{|l|}{ IRR } \\
\hline \multicolumn{10}{|l|}{ B. W/ CLP } \\
\hline \multicolumn{10}{|l|}{ GROSS BENEFITS } \\
\hline Sales from Copra & $11,119.68$ & $37,864.32$ & $25,396.80$ & $35,193.60$ & $25,646.40$ & $16,011.84$ & $13,840.32$ & $35,006.40$ & $29,278.08$ \\
\hline Sales from Pruned Leaves & $5,990.40$ & $7,987.20$ & $7,987.20$ & $7,987.20$ & $7,987.20$ & $7,987.20$ & $7,987.20$ & $7,987.20$ & $7,987.20$ \\
\hline TOTAL GROSS BENEFITS & PHP 69,062.24 & $78,902.20$ & $45,392.88$ & $65,858.00$ & $56,961.84$ & $30,340.44$ & $41,309.84$ & $62,312.64$ & $49,904.92$ \\
\hline \multicolumn{10}{|l|}{ GROSS COSTS } \\
\hline $\begin{array}{l}\text { Operating and Maintenance } \\
\text { Expenses }\end{array}$ & $27,785.64$ & $36,453.83$ & $31,292.93$ & $35,606.88$ & $31,647.74$ & $27,642.78$ & $27,525.67$ & $35,065.22$ & $32,762.96$ \\
\hline TOTAL GROSS COSTS & PHP 27,785.64 & $36,453.83$ & $31,292.93$ & $35,606.88$ & $31,647.74$ & $27,642.78$ & $27,525.67$ & $35,065.22$ & $32,762.96$ \\
\hline NET BENEFIT & PHP 41,276.60 & $42,448.37$ & $14,099.95$ & $30,251.12$ & $25,314.10$ & $2,697.66$ & $13,784.17$ & $27,247.42$ & $17,141.96$ \\
\hline NPV (12\%) PhP & PHP 139,107.10 & & & & & & & & \\
\hline BCR & 0.82 & & & & & & & & \\
\hline IRR & & & & & & & & & \\
\hline
\end{tabular}


Basic assumptions:

I. Production Cost
A. Coconut
Ringweediing
13min/tree @ 2x/yr
Fertilization
$14 \mathrm{~min} /$ tree
Leaf pruning (initial)
$7 \mathrm{~min} /$ tree
Every 45 days
3.5min/tree @ 8x/yr
Copra making
$25 \%$ of copra yield

\section{B. Coffee}
Ringweeding
Fertilization
Spraying
Pruning of coffee sprouts
Harvesting/processing
C. Fertilizer Cost

$$
\begin{aligned}
& 5 \mathrm{~min} / \mathrm{t} @ 6 \mathrm{x} / \mathrm{yr} \\
& 3 \mathrm{~min} / \mathrm{t} @ 2 x / y r \\
& 4 \mathrm{md} / \mathrm{yr}
\end{aligned}
$$$$
8.7 \mathrm{md} / \mathrm{yr}
$$
PhP1/kg of green bean
Ammonium Sulfate
Potassium Chloride
PhP240/bag
PhP350/bag
Zinc Sulfate
PhP350.0/bag
D. Labor Cost
PhP80.0/day

\section{Income}
A. Pruned frond for fuel
PhP 2.0/frond
B. Stickbroom
$\mathrm{PhP} \quad 2.0 / \mathrm{pc}$
C. Copra price
PhP $10 / \mathrm{kg}$
D. Coffee price
$\mathrm{PhP} \quad 65 / \mathrm{kg}$ 